\title{
Nitrous oxide flux from nitric-acid-treated cattle slurry applied to grassland under semi-controlled conditions
}

\section{G.L. VELTHOF \& O. OENEMA}

NMI, Department of Soil Science and Plant Nutrition, Wageningen, Agricultural University, P,O. Box 8005, NL 6700 EC Wageningen, Netherlands

Received 7 October 1992; accepted 4 February 1993

\begin{abstract}
Nítrous oxide $\left(\mathrm{N}_{2} \mathrm{O}\right)$ fluxes from cattle slurry after surface application to grassland were measured under semi-controlled environmental conditions during three periods in 1991. Three types of cattle slurry were examined: untreated slurry and slurries treated with nitric acid $\left(\mathrm{HNO}_{3}\right)$ to $\mathrm{pH} 6.0$ and 4.5. Treatiment with $\mathrm{HNO}_{3}$ is a proposed technique to reduce ammonia volatilization from slurry during storage, and during and after surface application. $\mathrm{N}_{2} \mathrm{O}$ flux was determined one to four times a day for 7 to 18 days after application of 0.64 to $3,8 \mathrm{~kg}$ slurry $\mathrm{m}^{-2}$. Slurry-derived fluxes were much higher from treated slurries than from untreated slurries. Cumulative $\mathrm{N}_{2} \mathrm{O}$ losses ranged from less than $0.2 \%$ of the mineral $\mathrm{N}$ applied via untreated slurry to a maximum of $3.4 \%$ of mineral $\mathrm{N}$ for treated slurry of $\mathrm{pH} 6.0$, which was stored for one week before application. $\mathrm{N}_{2} \mathrm{O}$ fluxes from slurry of $\mathrm{pH} 6.0$ and those from slurry of $\mathrm{pH} 4.5$ were similar, provided that the $\mathrm{pH}-6.0$ slurry was treated one hour before application. Differences between treatments with treated slurry and those with calcium ammonium nitrate were relatively small; apparently the amount of $\mathrm{NO}_{3}^{-} \mathrm{N}$ applied controlled the $\mathrm{N}_{2} \mathrm{O}$ flux: Regular irrigation strongly increased $\mathrm{N}_{2} \mathrm{O}$ fluxes.
\end{abstract}

Keywwords: nitrous oxide, grassland, cattle slurry, treated cattle slurry, nitric acid

\section{Introduction}

One of the measures to reduce ammonia $\left(\mathrm{NH}_{3}\right)$ emission from animal slurries is the acidification of these slurries. Studies in the United Kingdom have shown that acidification of animal slurry to pH 5.5-6.0 with sulphuric acid $\left(\mathrm{H}_{2} \mathrm{SO}_{4}\right)$ reduced $\mathrm{NH}_{3}$ losses' by 30-95 \% after surface application (Frost et al., 1990; Pain et al., 1990; Stevens et al. 1989; 1992). Similar results were obtained by Bussink \& Bruins (1992) for slurries treated with nitric acid $\left(\mathrm{HNO}_{3}\right)$. Addition of $\mathrm{HNO}_{3}$ also increases the fertilizer value of the slurry because the entrapped $\mathrm{NH}_{3}$ and added nitrate $\left(\mathrm{NO}_{3}^{-}\right)$ are both directly available for uptake by plants.

Howeyer, addition of $\mathrm{HNO}_{3}$ to generally anaerobic and carbon-rich slurry may promote denitrification, the microbial reduction of $\mathrm{NO}_{3}^{-}$into gaseous nitrous oxide $\left(\mathrm{N}_{2} \mathrm{O}\right)$ and dinitrogen $\left(\mathrm{N}_{2}\right)$ (Firestone \& Davidson, 1989). Denitrification leads to a loss of plant available $\mathrm{N}$ and also to an increase in slurry $\mathrm{pH}$ (Oenema \& Velthof, 1993). Furthermore, there may be an increased emission of $\mathrm{N}_{2} \mathrm{O}$ as it is one of the 


\section{G. L, VELTHOF AND O. OENEMA}

volatile products of denitrification. Indeed, $\mathrm{N}_{2} \mathrm{O}$ fluxes from cattle slurry treated with $\mathrm{HNO}_{3}$ were much higher than those from untreated slurry during storage for up to six months (Oenema \& Velthof, 1993). $\mathrm{N}_{2} \mathrm{O}$ is suspected of a probable contribution to global warming and to destruction of ozone in the stratosphere (Bouwman, 1990). The aim of the experiments described here was to determine the $\mathrm{N}_{2} \mathrm{O}$ flux from grassland after surface application of untreated slurry and slurries treated with $\mathrm{HNO}_{3}$ to $\mathrm{pH} 6.0$ and 4.5.

Currently, two variants of the slurry acidification procedure are tested in practice, i.c, acidification to $\mathrm{pH} 6.0$ just before surface application and acidification to $\mathrm{pH} 4.0$ to 4.5 immediately after deposition of the slurry by the cattle in the barn. In the latter variant, the $\mathrm{HNO}_{3}$ treated slurry may be stored for up to 6 months before surface application. Slurries of both variants, with some modifications, were examined.

A soil cover chamber technique was chosen to measure the $\mathrm{N}_{2} \mathrm{O}$ flux, because this technique is most appropriate for measuring small areas that are manipulated by fertilization (Mosier, 1989). A major problem in making reliable estimates of the flux from (un)fertilized grassland, based upon chamber measurements, is spatial variability. We assumed that this problem could be reduced by using a newly established sward on homogeneous soil in columns in which the groundwater level was fixed. We also assumed that irrigation increases soil moisture content and, thereby, $\mathrm{N}_{2} \mathrm{O}$ flux.

\section{Materials and methods}

\section{Materials}

Measurements were carried out with cattle slurries in three experiments during periods from 10 to 17 June, 21 to 30 August and 30 September to 17 October 1991. The slurries were applied to a grass sward in stainless steel columns (internal diameter $20 \mathrm{~cm}$, height $30 \mathrm{~cm})$. Each column contained $12 \mathrm{~kg}$ sandy soil with a pH $(\mathrm{KCl})$ of $4.74,7.05 \%$ organic matter, $4.6 \%$ clay, $10.3 \%$ silt, $59.1 \%$ fine sand and $26.0 \%$ coarse sand. Lolitum perenne L. was the dominant grass species in the one-year-old sward. The columns were placed in the open, on a dish with $2 \mathrm{~cm}$ of water to keep the soil moisture status constant. During nights and during periods of rainfall, a mobile greenhouse covered the columns.

Cattle slurry was obtained from a local dairy farm. The slurry was acidified to $\mathrm{pH}$ 6.0 and 4.5 with $10.3 \mathrm{M} \mathrm{HNO}_{3}$. In the first experiment, the slurry was acidified one weck before application. In the second and third experiments slurries of $\mathrm{pH} 6.0$ were acidified one hour and those of $\mathrm{pH} 4.5$ one week before application. During storage at $15^{\circ} \mathrm{C}$ for one week, the slurries were homogenized regularly and the $\mathrm{pH}$ was kept at the target $\mathrm{pH}$ by addition of $\mathrm{HNO}_{3}$ if necessary. The untreated slurry was also homogenized regularly.

Concentrations of $\mathrm{NH}_{4}^{+}, \mathrm{NO}_{3}^{-}$and $\mathrm{N}_{2} \mathrm{O}$ in the slurries were measured according to the procedures described by Oenema et al. (1993). The chemical composition and application rates of the slurries in all three experiments are given in Table 1. The homogenized slurries were applied with a pipette to the sward, which was cut one day before application. 


\section{Experimental design}

The first two experiments had a split-plot design with treatments in four replicates. Irrigation was the main factor. There were five treatments in type and rate of slurry: untreated slurry, treated slurry of $\mathrm{pH} 6.0$, treated slurry of $\mathrm{pH} 4.5$ at two application rates and a control. All these treatments were carried out with and without irrigation. When irrigated, treatments received about $5 \mathrm{~mm}$ water per day from a sprinkler installation. $\mathrm{N}_{2} \mathrm{O}$ flux was measured once a day between 9.00 and 12.00 a.m., for 7 to 9 consecutive days. ".

The third experiment had a randomized block design with treatments in four replicates. The treatments were: untreated slurry, treated slurries of $\mathrm{pH} 6.0$ and 4.5 , calcium ammonium nitrate (CAN), a control and an additional treatment in which treated slurry of pH 4.5 was applied to inert quartzitic sand without a grass sward. The latter treatment was included to determine the effect of soil and sward on $\mathrm{N}_{2} \mathrm{O}$ flux. All treatments were irrigated every two days with $5 \mathrm{~mm}$ water. $\mathrm{N}_{2} \mathrm{O}$ fluxes were measured four times a day during the first four days, usually starting at 3.00 and 9.00 a.m., and at 3.00 and 9.00 p.m.; thereafter one to two times per day, starting at $9.00 \mathrm{a} . \mathrm{m}$. and $15.00 \mathrm{p} . \mathrm{m}$.

\section{Flux measurements}

Measurements were carried out with vented closed chambers (Mosier, 1989). The circular PVC chambers (internal diameter $25 \mathrm{~cm}$ and height $10 \mathrm{~cm}$ ) had a collar of insulation foam attached to the bottom to minimize gas exchange with the outside atmosphere. The flux was calculated from the increase in $\mathrm{N}_{2} \mathrm{O}$ concentration in the headspace of the chambers with time. Slurry-derived $\mathrm{N}_{2} \mathrm{O}$ flux was calculated by substracting the average $\mathrm{N}_{2} \mathrm{O}$ flux from the unfertilized control treatment.

In experiment $\mathrm{I}$, the headspace of the chambers was sampled with $12 \mathrm{ml}$ polypropylene syringes via rubber septa in the lid three times, usually after 0,30 and 60 minutes. All samples were analyzed by gaschromatography within two days after sampling.

Because of the time consuming procedure and the possible errors introduced via sampling and sample storage, $\mathrm{N}_{2} \mathrm{O}$ was measured with a photo-acoustic infra-red gas analyzer in experiments II and III. The analyzer was directly attached to the chambers, using polytetrafluorethylene tubes (internal diameter $0.3 \mathrm{~cm}$, length $75 \mathrm{~cm}$ ) with traps of soda lime and magnesium perchlorate to remove $\mathrm{CO}_{2}$ and $\mathrm{H}_{2} \mathrm{O}$, respectively. A gas sample was taken and analyzed for $\mathrm{N}_{2} \mathrm{O}$ automatically about every minute, after the air in the headspace of the chamber was pumped around for $30 \mathrm{~s}$ at a flow rate of $30 \mathrm{ml} \mathrm{s}^{-1}$. All 5 or 6 treatments within one replicate were measured sequentially. This procedure was repeated four or five times, so that all treatments were measured four or five times at regular time intervals during an enclosure period of 30 to 40 minutes. Immediately thereafter, the treatments in the other three replicates were measured sequentially.

The increase in the $\mathrm{N}_{2} \mathrm{O}$ concentration in the headspace was linear with time. Generally, the linear correlation coefficient $\left(r^{2}\right)$ was $\geq 0.98$ and the precision of the 


\section{G, L. VELTHOF AND O. OENEMA}

calculated flux was high. However, if the $\mathrm{N}_{2} \mathrm{O}$ concentration increased less than about 3 ppbv per minute and the flux was less than about $0.03 \mathrm{mg} \mathrm{N} \mathrm{m}^{-2} \mathrm{hr}^{-1}, \mathrm{r}^{2}$ was usually less than 0.98 (Fig. 1). Thus, the precision of the calculated flux increased with increasing flux. The unit ppbv is equivalent to $\mu \mathrm{m}^{-3}$.

\section{Analytical procedures}

$\mathrm{NO}_{3}^{-}$and $\mathrm{NH}_{4}^{+}$were analyzed by standard auto-analyzer methods (Technicon: US no 824-87T and US no 795-86T, respectively). $\mathrm{N}_{2} \mathrm{O}$ was measured via a $\mathrm{PU} 4400$ gaschromatograph equipped with $27.5 \mathrm{~m}$ Porapak $\mathrm{Q}$ wide bore column and a ${ }^{63} \mathrm{Ni}$ electron capture detector (ECD) or via a photo-acoustic spectroscopic Gas Monitor Type 1302 of Brüel \& Kjar, equipped with the optical filters UA 0982, UA 0985 and SB 0527. Analysis of gas standards with $\mathrm{N}_{2} \mathrm{O}$ concentation in the $300-1000$ ppbv range, showed that the accuracy of the $\mathrm{N}_{2} \mathrm{O}$ analyses was within $5 \%$ when measured with the gas monitor in the field.

\section{Results and discussion}

\section{Composition of slurries}

The large differences in slurry composition (Table 1) were due to slurry origin and treatment. The initial $\mathrm{pH}$, dry matter and $\mathrm{NH}_{4}^{+}$contents, and acid neutralizing capacity of the slurry of experiment I were higher than those of the slurries of experiments II and III. Differences between slurries within one experiment were the result of slurry acidification. Addition of $\mathrm{HNO}_{3}$ increased the $\mathrm{NO}_{3}^{-}$content and decreased $\mathrm{NH}_{3}$ volatilization so that treated slurries had higher $\mathrm{NH}_{4}^{+}$contents than untreated
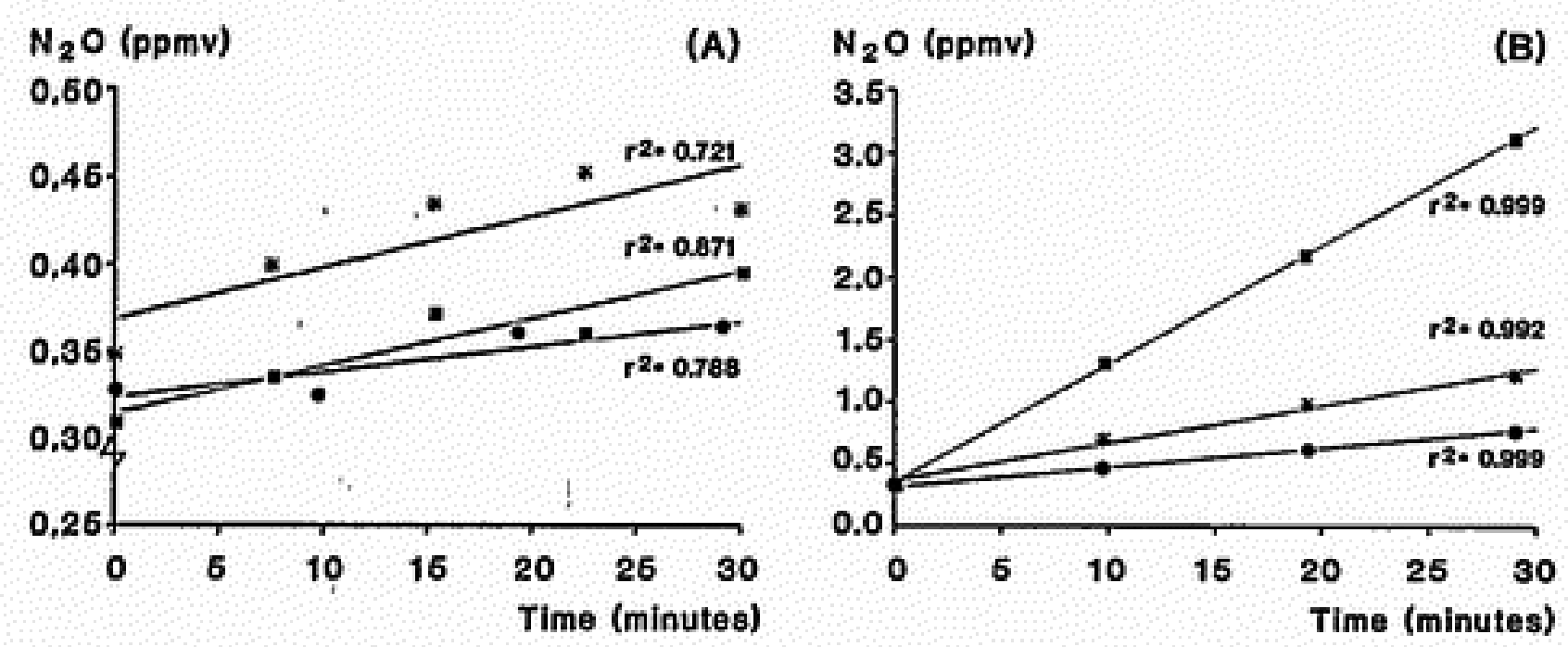

Fig. 1. Changes in the $\mathrm{N}_{2} \mathrm{O}$ concentration in the headspace of vented closed chambers on a fertilized grass sward with time, illustrating the effect of flux rate on precision of the flux. Relatively low concenIration increases and a corresponding low linear correlation coefficient $\left(r^{2}\right)$ are shown in $A$; rapid increases and high $\mathrm{r}^{2}$ in $\mathrm{B}$. The $\mathrm{N}_{2} \mathrm{O}$ concentration was measured with a photo-acoustic infra-red gas analyzer directly atlached to the chamber. 
Table 1. Some chemical properties and application rates of the slurries. Samples were taken just before application to the grass sward.

\begin{tabular}{|c|c|c|c|c|c|c|c|}
\hline Expt & Slurry & $\mathrm{pH}$ & $\begin{array}{l}\text { Dry } \\
\text { matter } \\
\left(\mathrm{g} \mathrm{kg}^{-1}\right)\end{array}$ & $\begin{array}{l}\mathrm{NH}_{4}^{+}-\mathrm{N} \\
\left(\mathrm{g} \mathrm{kg}^{-1}\right)\end{array}$ & $\begin{array}{l}\mathrm{NO}_{3}^{-}-\mathrm{N} \\
\left(\mathrm{g} \mathrm{kg}^{-1}\right)\end{array}$ & $\begin{array}{l}\mathrm{N}_{2} \mathrm{O}-\mathrm{N} \\
\left(\mathrm{mg} \mathrm{kg}^{-1}\right)\end{array}$ & $\begin{array}{l}\text { Application } \\
\text { rates } \\
\left(\mathrm{kg} \mathrm{m}^{-2}\right)\end{array}$ \\
\hline I & $\begin{array}{l}\text { Untreated } \\
\mathrm{pH} 6.0^{*} \\
\mathrm{pH} 4.5^{*}\end{array}$ & $\begin{array}{l}7.4 \\
6.0 \\
4.4\end{array}$ & $\begin{array}{l}110 \\
113 \\
123\end{array}$ & $\begin{array}{l}2.18 \\
2.40 \\
2.79\end{array}$ & $\begin{array}{l}0.02 \\
1.94 \\
4.41\end{array}$ & $\begin{array}{l}0.02 \\
6.34 \\
0.07\end{array}$ & $\begin{array}{l}1.27 \\
1.27 \\
0.64\end{array}$ \\
\hline II & $\begin{array}{l}\text { Untreated } \\
\text { pH } 6.0^{* *} \\
\text { pH } 4.5^{*}\end{array}$ & $\begin{array}{l}7.0 \\
6.0 \\
4.5\end{array}$ & $\begin{array}{r}90 \\
108 \\
109\end{array}$ & $\begin{array}{l}1.32 \\
1.82 \\
1.89\end{array}$ & $\begin{array}{l}0.00 \\
1.19 \\
3.58\end{array}$ & $\begin{array}{l}0.01 \\
0.41 \\
0.13\end{array}$ & $\begin{array}{ll}1.27 & \\
1.27 & \\
0.64 & 1.27\end{array}$ \\
\hline III & $\begin{array}{l}\text { Untreated } \\
\text { pH } 6.0^{* *} \\
\text { pH } 4.5^{*} \\
\text { CAN }\end{array}$ & $\begin{array}{l}6.9 \\
6.0 \\
4.5 \\
-\end{array}$ & $\begin{array}{r}112 \\
- \\
-\end{array}$ & $\begin{array}{r}1.91 \\
2.23 \\
2.51 \\
13.50\end{array}$ & $\begin{array}{r}0.00 \\
1.32 \\
4.07 \\
13.50\end{array}$ & $\begin{array}{l}-* * * \\
- \\
- \\
-\end{array}$ & $\begin{array}{l}3.82 \\
2.22 \\
1.27 \\
0.03\end{array}$ \\
\hline
\end{tabular}

* Slurry acidified one week before application. ** Slurry acidified one hour before application. *** Not analyzed.

slurries, which contained no or only traces of $\mathrm{NO}_{3}^{-}$.

The dissolved $\mathrm{N}_{2} \mathrm{O}$ content of the pH-6.0 slurry was 15 times higher in the first experiment than in the second experiment (Table 1). Apparently, $\mathrm{N}_{2} \mathrm{O}$ accumulated in the slurry during storage for one week in the first experiment. The relatively low $\mathrm{N}_{2} \mathrm{O}$ contents in the untreated and in the $\mathrm{pH}-4.5$ slurries suggest that $\mathrm{N}_{2} \mathrm{O}$ production rate was low in these slurries. Under conditions favourable for denitrification up to $500 \mathrm{mg} \mathrm{N} \mathrm{N}_{2} \mathrm{O}-\mathrm{N}$ per $\mathrm{kg}$ slurry can accumulate in slurries of $\mathrm{pH} 6.0$ (Oenema \& Velthof, 1993).

\section{Variability of $\mathrm{N}_{2} \mathrm{O}$ fluxes}

Fluxes of $\mathrm{N}_{2} \mathrm{O}$ were rather low during most measurements, but in some treatments and on some dates, the flux was very high. The frequency distributions of the fluxes in the three experiments were highly skewed and lognormal.

The coefficient of variation of the average flux of four replicates ranged from 4 to $200 \%$ with an average of $83 \%$ (Fig. 2). A high coefficient of variation is typical for $\mathrm{N}_{2} \mathrm{O}$ fluxes from grassland and other terrestrial systems, when measured with a flux chamber technique (Mosier, 1989). In an attempt to reduce the variability within treatments we performed the measurements under semi-controlled conditions, using thoroughly homogenized sandy soil with a uniform and constant soil moisture status. However, the results of this study suggest that the within-treatment variability may be also large in columns with uniform sward and treatment. Probably, slight differences between columns in percolation rate may have increased the variability. The variability within treatments remained high throughout the experimental period; columns with a relatively high flux at the start of the experiment kept a strong source 


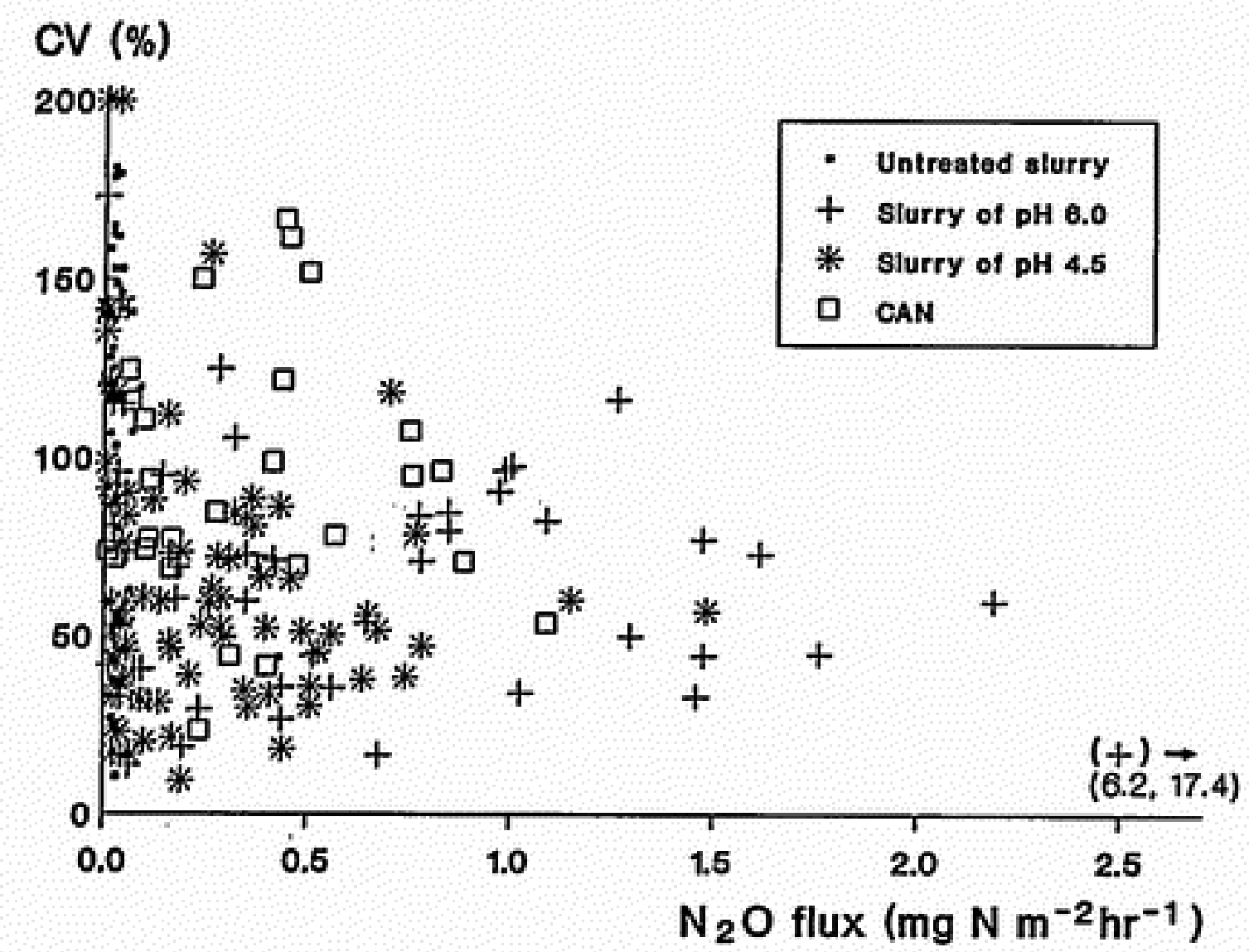

Fig. 2. Mean $\mathrm{N}_{2} \mathrm{O}$ fluxes versus coefficients of variation (CV). Means and CVs were obtained from four flux measurements.

strength; low initial rates remained low.

Type of slurry and fertilizer did not clearly affect the coefficient of variation. Coefficients of variation slightly decreased with an increase in the $\mathrm{N}_{2} \mathrm{O}$ flux (Fig. 2).

$\mathrm{N}_{2} \mathrm{O}$ fluxes: experiments I and II

Fluxes of $\mathrm{N}_{2} \mathrm{O}$ from the control treatments were usually lower than $0.01 \mathrm{mg} \mathrm{N} \mathrm{m}^{-2}$ $\mathrm{hr}^{-1}$. Slurry-derived fluxes from treatments with untreated slurry were also low, i.e. less than $0.04 \mathrm{mg} \mathrm{N} \mathrm{m}^{-2} \mathrm{hr}^{-1}$ in both experiments. Slurry-derived fluxes were 1 to 2 orders of magnitude higher from $\mathrm{HNO}_{3}$ treated slurries than from untreated slurry in both experiments and for both $\mathrm{pH}$ levels.

There are two main biological sources of $\mathrm{N}_{2} \mathrm{O}$, viz. denitrification and nitrification (Firestone \& Davidson, 1989). The fact that $\mathrm{N}_{2} \mathrm{O}$ flux was high after application of treated slurry and low after application of $\mathrm{NO}_{3}^{-}$free untreated slurry suggests that denitrification was the dominant source of $\mathrm{N}_{2} \mathrm{O}$ in the experiments. Nitrification of slurry $\mathrm{NH}_{4}^{+}$, possibly in combination with subsequent denitrification, was a minor source of $\mathrm{N}_{2} \mathrm{O}$, as total amounts of $\mathrm{N}_{2} \mathrm{O}$ emitted after application of untreated slurry were low.

The mean flux from the $\mathrm{pH} 6.0$ treatment was much higher in the first than in the second experiment (Fig. 3). This could be an effect of the duration of slurry treatment before application; in experiment I, $\mathrm{HNO}_{3}$ was added one week, and in experiment II, one hour before application. Apparently, the denitrifying population was 


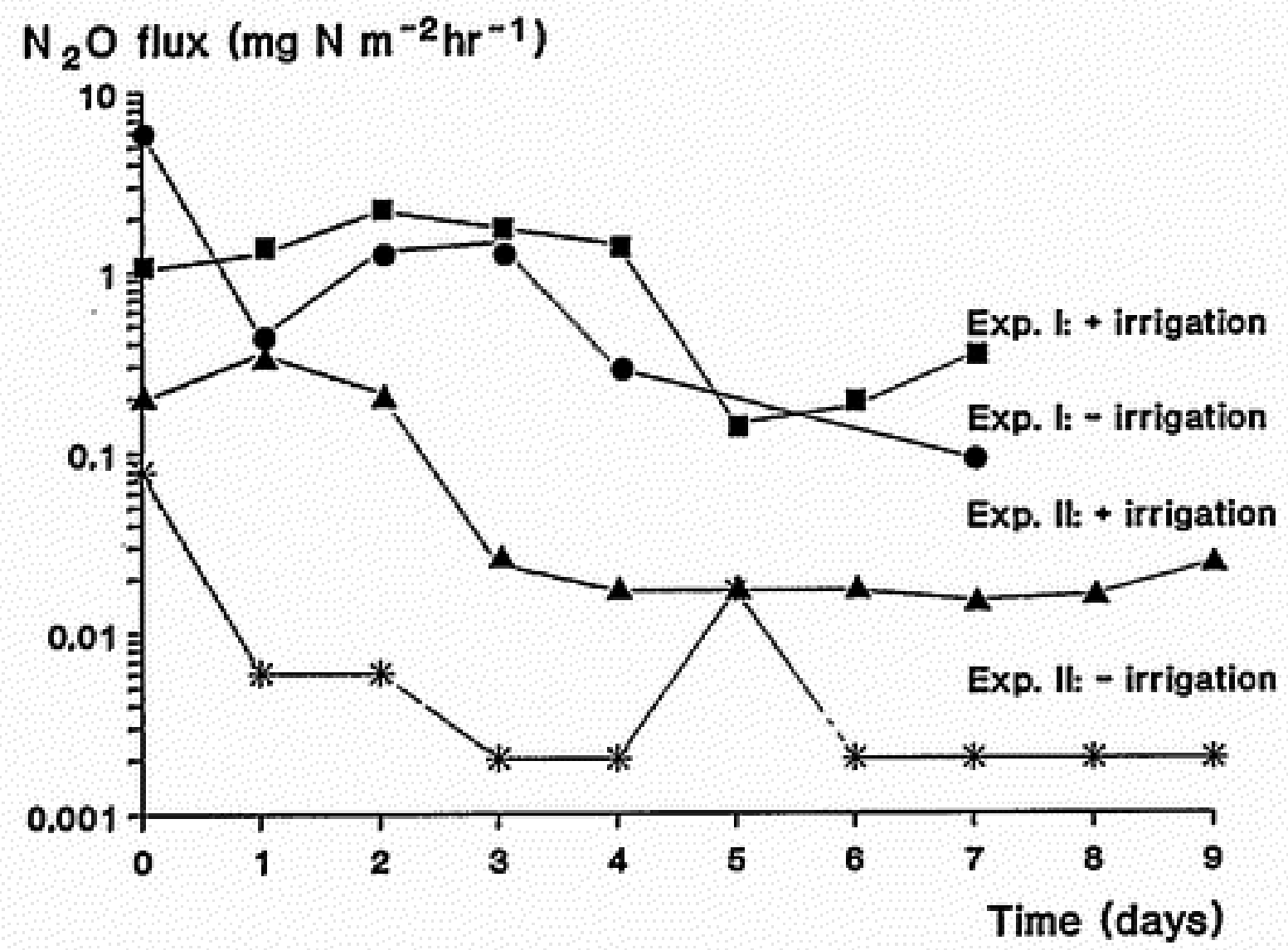

Pig. 3. Slurry-derived $\mathrm{N}_{2} \mathrm{O}$ fluxes from treated cattle slurry of $\mathrm{pH} 6.0$ applied at a rate of $1.27 \mathrm{~kg} \mathrm{~m}^{-2}$ to the surface of a grass sward with and without daily irrigation. Means of four replicates, from experiments I and II. Note logarithmic scale of Y axis.

much more active one week after addition of $\mathrm{HNO}_{3}$ than one hour after addition. The fact that the concentration of dissolved $\mathrm{N}_{2} \mathrm{O}$ was higher in the one-week-old than in the one-hour-old $\mathrm{pH}-6.0$ slurry (Table 1 ) supports this suggestion, just as the large flux immediately after application of one-week-old slurry (Fig. 3).

In experiment $\mathrm{I}, \mathrm{N}_{2} \mathrm{O}$ flux was lower from the $\mathrm{pH} 4.5$ treatment than from the $\mathrm{pH}$ 6,0 treatment (Table 2). In experiment II, fluxes showed little variation, indicating that slurry acidified to $\mathrm{pH} 6.0$ one hour before application behaved similar to oneweek-old slurry of $\mathrm{pH} 4.5$.

An increase in application rate from 0.64 to $1.27 \mathrm{~kg} \mathrm{~m}^{-2}$ increased the flux from the pH 4.5 treatment (Figure 4). This agrees with the conclusion of Eichner (1990) and Bouwman (1990) that $\mathrm{N}_{2} \mathrm{O}$ fluxes generally increase with increasing $\mathrm{N}$ application rate.

Irrigation increased $\mathrm{N}_{2} \mathrm{O}$ fluxes from all treatments in experiments I and II (Fig. 3). In some treatments irrigation increased fluxes by more than one order of magnitude, The effect of irrigation may suggest that denitrification was the dominant source of $\mathrm{N}_{2} \mathrm{O}$. Water in slurry and soil may act as a barrier to oxygen $\left(\mathrm{O}_{2}\right)$ diffusion and may stimulate microbial consumption of trapped $\mathrm{O}_{2}$, resulting in reducing conditions and increased denitrification in slurry and soil. 


\section{G. L. VELTHOF AND O. OENEMA}

Table 2, Summed slurry- and CAN-derived $\mathrm{N}_{2} \mathrm{O}$ losses $\left(\mathrm{mg} \mathrm{N} \mathrm{m}^{-2}\right)$ and as a percentage of mineral $\mathrm{N}$ and $\mathrm{NO}_{3}^{-}-\mathrm{N}$ applied during the three experiments.

\begin{tabular}{|c|c|c|c|c|c|c|c|c|}
\hline \multirow[t]{3}{*}{ Expt } & \multirow[t]{3}{*}{ Treatment } & & \multirow{2}{*}{\multicolumn{2}{|c|}{$\begin{array}{l}\mathrm{N} \text { application } \\
\text { rate }\end{array}$}} & \multirow{3}{*}{$\begin{array}{l}\text { Regular } \\
\text { irrigation }\end{array}$} & \multicolumn{3}{|c|}{$\mathrm{N}_{2} \mathrm{O}-\mathrm{N}$ emitted } \\
\hline & & & & & & \multirow[t]{2}{*}{$\mathrm{mg} \mathrm{m}^{-2}$} & \multicolumn{2}{|c|}{$\%$ of $\mathrm{N}$ applied } \\
\hline & & & $\begin{array}{l}\text { mineral } \\
\left(\mathrm{g} \mathrm{m}^{-2}\right)\end{array}$ & $\begin{array}{l}\mathrm{NO}_{3}^{-} \\
\left(\mathrm{g} \mathrm{m}^{-2}\right)\end{array}$ & & & mineral & $\mathrm{NO}_{3}^{-}-\mathrm{N}$ \\
\hline \multirow[t]{8}{*}{ I } & Untreated & & 2.8 & 0.0 & - & $<2$ & $<0.1$ & - \\
\hline & - & $\therefore$ & $\therefore$ & & + & $<3$ & $<0.2$ & - \\
\hline & pH 6.0 & & 5.6 & 2.5 & - & 163 & 2.9 & 6.5 \\
\hline & & & & & + & 193 & 3.4 & 7.7 \\
\hline & $\mathrm{pH} 4.5$ & & 9.1 & 5.6 & - & $<6$ & $<0.1$ & $<0.1$ \\
\hline & & & & & + & 48 & 0.5 & 0.9 \\
\hline & $\mathrm{pH} 4.5$ & & 4.6 & 2.8 & - & $<2$ & $<0.1$ & $<0.1$ \\
\hline & & & & & + & 36 & 0.8 & 1.3 \\
\hline \multirow[t]{8}{*}{ II } & Untreated & & 1.7 & 0.0 & - & $<2$ & $<0.2$ & - \\
\hline & & & & & + & 6 & 0.4 & - \\
\hline & $\mathrm{pH} 6.0$ & & 3.8 & 1.5 & - & $<3$ & $<0.1$ & $<0.2$ \\
\hline & & & & & + & 21 & 0.6 & 1.4 \\
\hline & $\mathrm{pH} 4.5$ & & 7.0 & 4.6 & - & $<3$ & $<0.1$ & $<0.1$ \\
\hline & & $\theta$ & & & + & 26 & 0.4 & 0.6 \\
\hline & $\mathrm{pH} 4.5$ & & 3.5 & 2.3 & - & $<1$ & $<0.1$ & $<0.1$ \\
\hline & & 1 & & & + & 14 & 0.4 & 0.6 \\
\hline \multirow[t]{5}{*}{ III } & Untreated & & 7.3 & 0.0 & + & 10 & 0.1 & - \\
\hline & $\mathrm{pH} 6,0$ & & 7.9 & 2.9 & + & 107 & 1.4 & 3.7 \\
\hline & $\mathrm{pH} 4.5$ & & 8.4 & 5.2 & + & 132 & 1.6 & 2.5 \\
\hline & CAN & & 7.2 & 3.6 & + & 90 & 1.2 & 2.5 \\
\hline & $\begin{array}{l}\text { pH } 4.5 \text { on } \\
\text { sand only }\end{array}$ &. & 8.4 & 5.2 & + & 9 & 0.1 & 0.2 \\
\hline
\end{tabular}

\section{$\mathrm{N}_{2} \mathrm{O}$ fluxes: experiment III}

In experiment III, $\mathrm{N}_{2} \mathrm{O}$ fluxes increased in the order: untreated slurry, CAN, treated slurries (Fig. 5A and Table 2). The low but significant slurry-derived flux from the $\mathrm{NO}_{3}^{-}$free untreated slurry suggests that $\mathrm{N}_{2} \mathrm{O}$ was released from nitrification of $\mathrm{NH}_{4}^{+}$, possibly in combination with subsequent denitrification.

The flux from treated slurries immediately after application, probably originated from the $\mathrm{N}_{2} \mathrm{O}$ pool in the slurries. No flux could be detected immediately after application of CAN. The highest slurry- and CAN-derived fluxes occurred during the second day. After this peak, fluxes decreased gradually with time and 17 days after application fluxes from fertilized columns were similar to those from unfertilized columns. There was no clear diurnal pattern in fluxes related to changes in soil temperature (Fig. 5A and B) as found by Blackmer et al. (1982) and Denmead et al. (1979). Possibly, the effect of temperature variations was masked by the effect of regular irrigation.

Fluxes from slurry of $\mathrm{pH} 4.5$ were equal to or only slightly higher than those from 


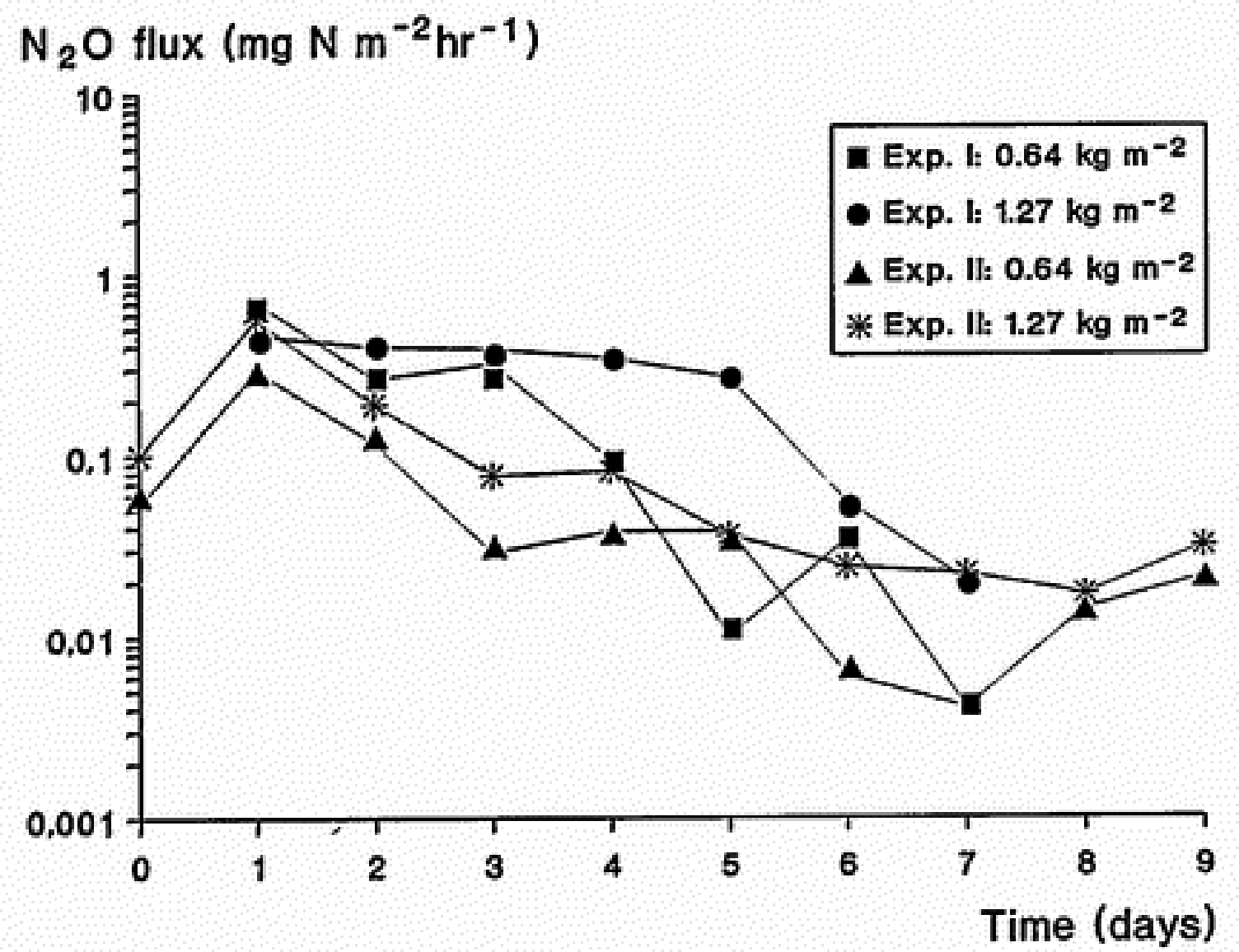

Fig. 4. Slurry-derived $\mathrm{N}_{2} \mathrm{O}$ fluxes from treated cattle slurry of $\mathrm{pH} 4.5$ surface-applied to a grass sward. Slurry was applied at rates of 0.64 and $1.27 \mathrm{~kg} \mathrm{~m}^{-2}$. All treatments were irrigated daily. Means of four replicates, from experiments I and II. Note logarithmic scale of $Y$ axis.

the slurry of $\mathrm{pH}$ 6.0. This corresponds with the results of experiment II and indicates that there was not an immediate effect of $\mathrm{pH}$ on $\mathrm{N}_{2} \mathrm{O}$ flux, provided that slurry of $\mathrm{pH}$ 6.0 was treated immediately before application.

Surprisingly, fluxes from CAN were on average only slightly lower than those from treated slurries. This suggests that the sandy soil contained sufficient amounts of readily available carbon and sites of anaerobiosis for denitrification and $\mathrm{N}_{2} \mathrm{O}$ production. With treated slurry both $\mathrm{NO}_{3}^{-}$and available carbon are applied. Application of slurry may also seal the soil, thereby creating anaerobic microsites in the soil with high denitrification activity, due to decreased $\mathrm{O}_{2}$ diffusion and increased $\mathrm{O}_{2}$ consumption (Beauchamp et al., 1989). The relatively small differences between CAN and treated slurries indicates that application of $\mathrm{NO}_{3}^{-}$was the most critical factor and that the soil was the dominant site of $\mathrm{N}_{2} \mathrm{O}$ production.

The flux pattern of the treatment with pH-4.5 slurry applied to quartzitic sand is shown in Fig. 6 . The flux from quartzitic sand was assumed to be negligible. During the first days no significant amounts of $\mathrm{N}_{2} \mathrm{O}$ were emitted, except immediately after slurry application. A small but significant flux was measured from day 5 onwards. Apparently, it took some time for $\mathrm{N}_{2} \mathrm{O}$ production to start in the sand-slurry environment. However, the fluxes were much lower from the quartzitic sand than from the sandy soil with sward. There are several possible explanations for these low fluxes, like the absence of soil organic matter, roots and a well-established denitrifying bacteria population in the quartzitic sand. Albeit unclear, the results of this treatment 
$\mathrm{N}_{2} \circ$ flux (mg N m${ }^{-2} \mathrm{hr}^{-1}$ )

(A)

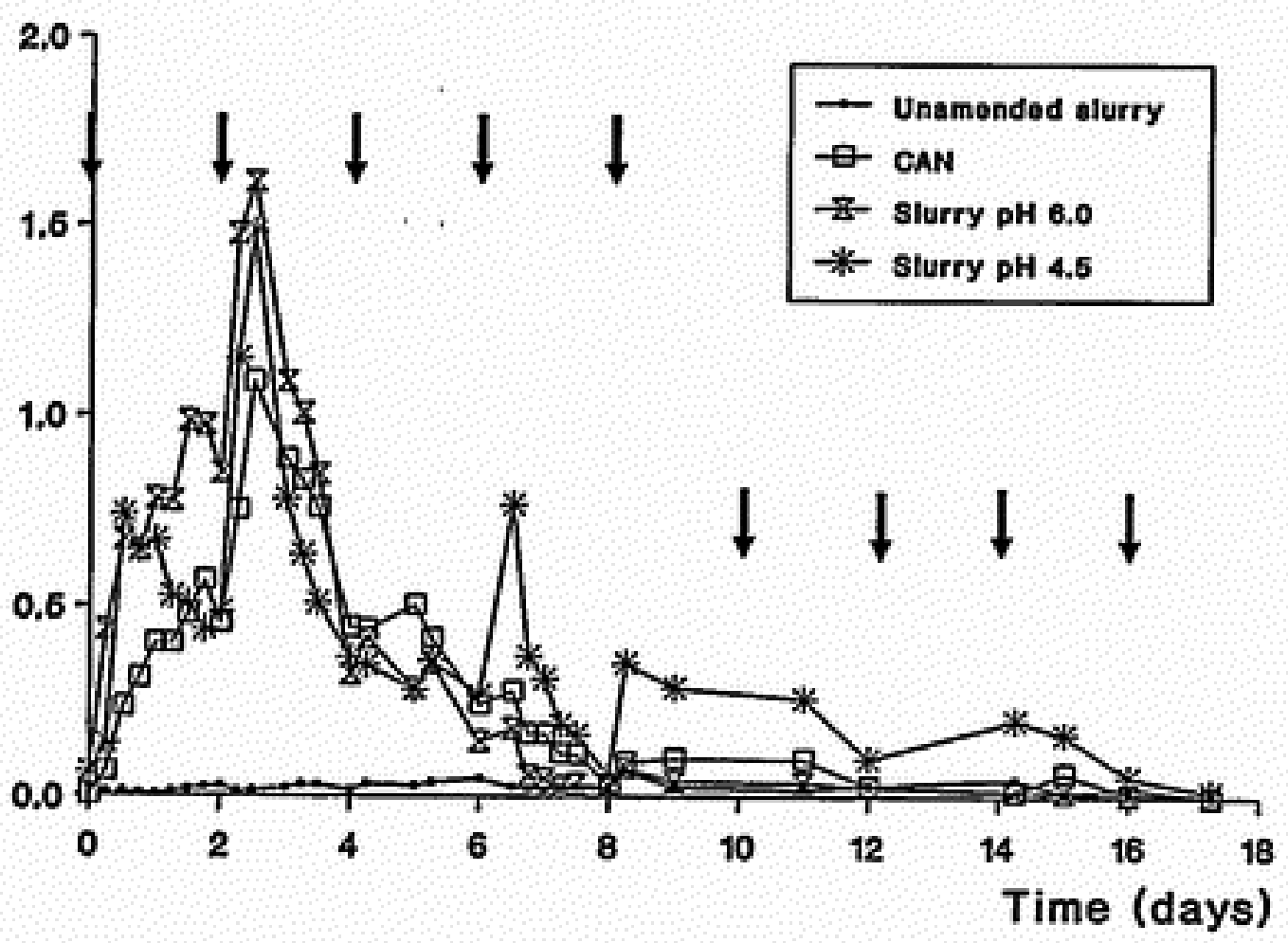

Temperature $\left({ }^{\circ} \mathrm{C}\right)$

(B)

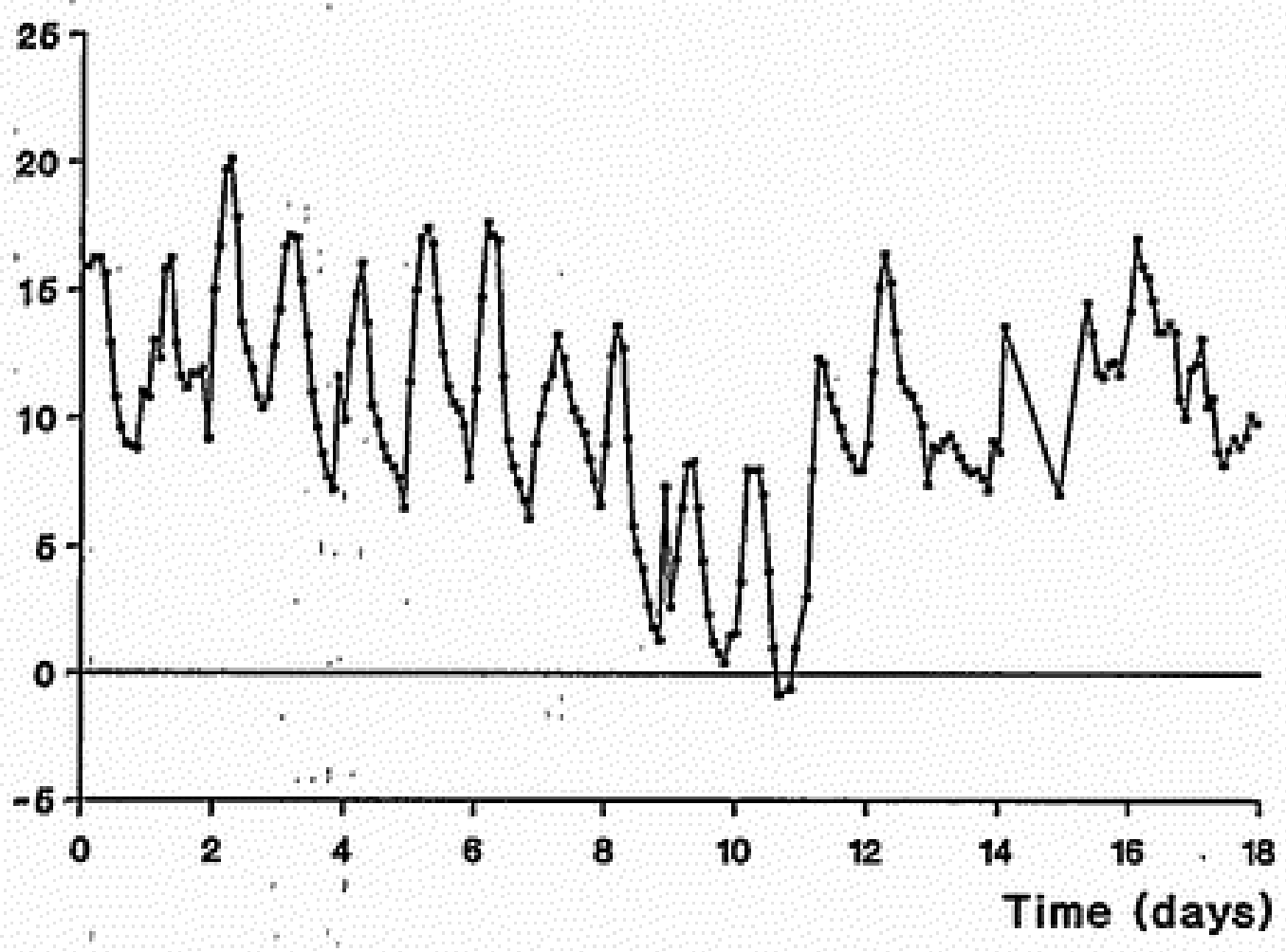

Fig. 5. (A) Slurry-derived $\mathrm{N}_{2} \mathrm{O}$ flux from untreated slurry, treated slurries of $\mathrm{pH}$ 6,0 and pH 4.5 and fertilized-derived flux from CAN, surface-applied to a grass sward. Arrows indicate time of irrigation. Means of four replicates, from experiment III. (B) Course of the air temperature during experiment III.

confirm the suggestion that $\mathrm{HNO}_{3}$ treated slurry itself was not the dominant site of $\mathrm{N}_{2} \mathrm{O}$ production. 


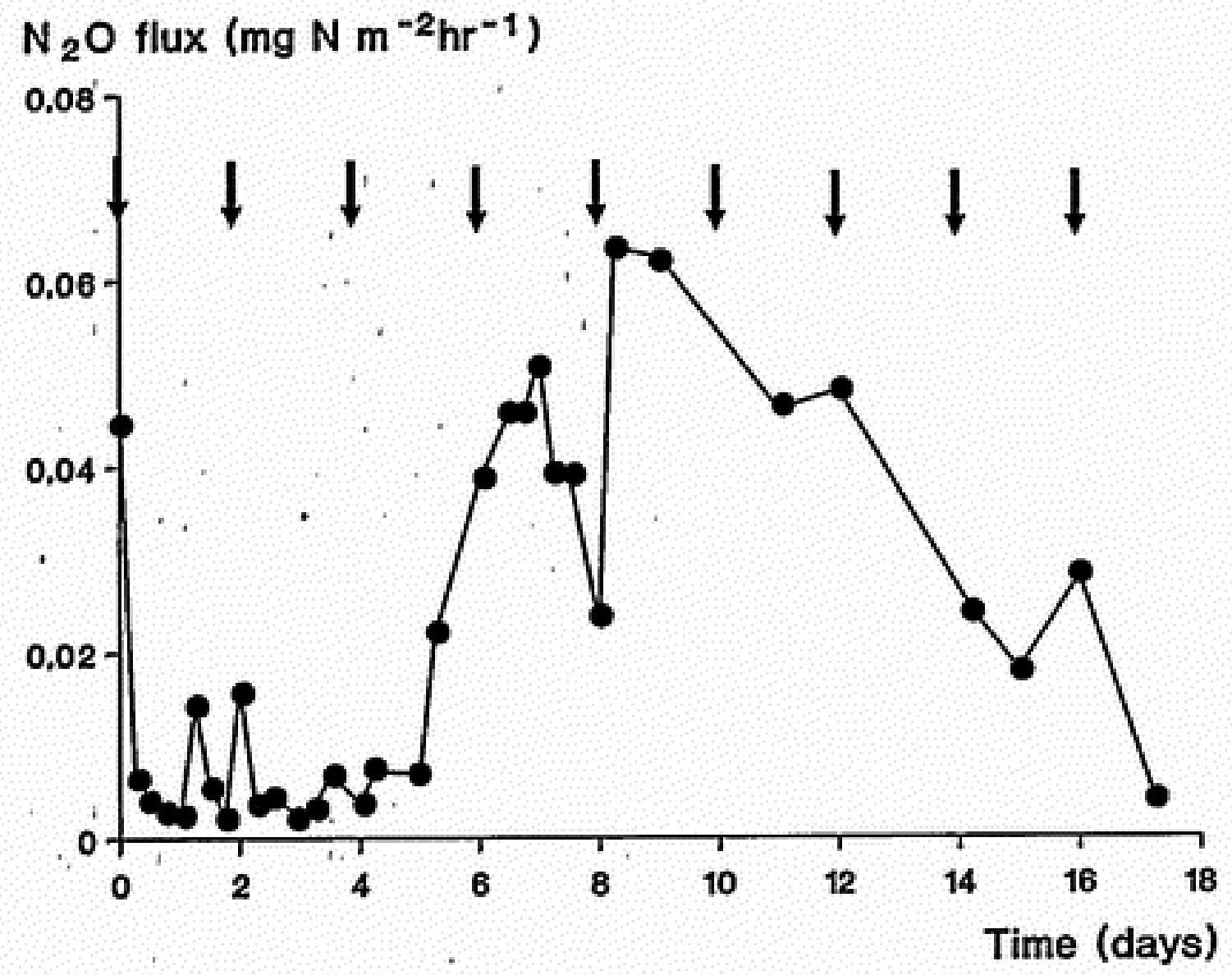

Pig. 6. Flux of $\mathrm{N}_{2} \mathrm{O}$ from slurry of $\mathrm{pH} 4.5$ surface-applied to quartzitic sand without a grass sward. Means of four replicates, from experiment III.

\section{Summed $\mathrm{N}_{2} \mathrm{O}$ losses}

The summed slurry-derived $\mathrm{N}_{2} \mathrm{O}$ losses were estimated by integrating the $\mathrm{N}_{2} \mathrm{O}$ flux over time. Summed losses were lower in experiment II than in experiments I and III (Table 2). Part of this difference may be attributed to differences in slurry composition and in the duration of the measurement periods. Differences in weather conditions and temperature may also have contributed (Table 3). During the warm and sunny weather conditions of experiment II, grass growth and $\mathrm{N}$ uptake was faster than during the colder and cloudy weather conditions of experiments II and III. Obviously, the faster $\mathrm{N}$ is absorbed by a crop, the smaller the risk of denitrification and $\mathrm{N}_{2} \mathrm{O}$ production. The overall effect of temperature on $\mathrm{N}_{2} \mathrm{O}$ flux is difficult to predict.

Table 3, Mean, minimum and maximum temperatures during experiments I, $\mathrm{II}$ and III.

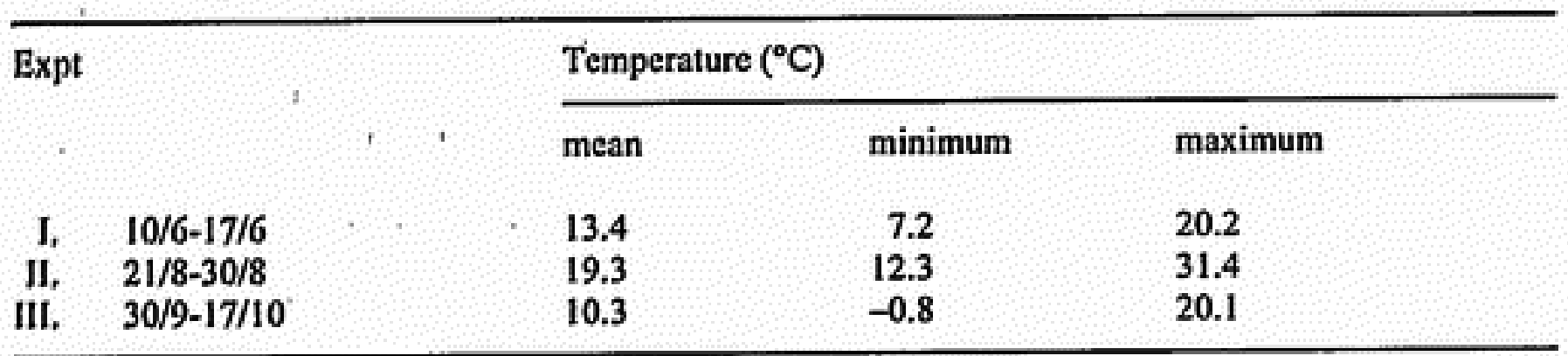


The denitrification rate increases with increasing temperatures, but the ratio between $\mathrm{N}_{2} \mathrm{O}$ and $\mathrm{N}_{2}$ produced during denitrification generally decreases (e.g. Keeney et al., 1979).

When irrigated, $\mathrm{N}_{2} \mathrm{O}$ fluxes $\left(\mathrm{mg} \mathrm{N} \mathrm{m}^{-2} \mathrm{hr}^{-1}\right.$ ) and summed $\mathrm{N}_{2} \mathrm{O}$ losses (in \% of $\mathrm{N}$ applied) were relatively high, but both are in the range of data reported in the literature (Eichner, 1990; Bouwman, 1990). Under non-irrigated conditions, losses were low. From an agricultural point of view, the total $\mathrm{N}_{2} \mathrm{O}-\mathrm{N}$ losses were relatively small; less than $3.4 \%$ of mineral $\mathrm{N}$ applied was emitted as $\mathrm{N}_{2} \mathrm{O}$ (Table 2). However, the proportion of $\mathrm{N}_{2} \mathrm{O}$ in the total $\mathrm{N}$ loss through denitrification may range from less than 5 up to more than $50 \%$ (Ryden \& Rolston, 1983). Hence, $\mathrm{N}_{2} \mathrm{O}-\mathrm{N}$ losses are a lower estimate of total $\mathrm{N}$ losses. The wide range indicates that it is impossible to deduce accurately total $\mathrm{N}$ losses from $\mathrm{N}_{2} \mathrm{O}$ production data only.

\section{Conclusions}

The major conclusions from these experiments are:

- Coefficients of variation of average $\mathrm{N}_{2} \mathrm{O}$ fluxes were relatively independent of slurry type and flux and, under the semi-controlled conditions of our experiments, as high as those reported for field conditions.

- $\mathrm{HNO}_{3}$ treated cattle slurry emitted much more $\mathrm{N}_{2} \mathrm{O}$ than untreated slurry; the amounts emitted by CAN were similar to those of treated cattle slurry.

- Irrigation markedly increased $\mathrm{N}_{2} \mathrm{O}$ fluxes from $\mathrm{HNO}_{3}$ treated slurries and CAN.

$-\mathrm{N}_{2} \mathrm{O}$ fluxes were highest during the first three days after application; subsequently decreased to rates equal to that of the unfertilized treatments within 5-14 days.

- Slurry $\mathrm{pH}$ had no clear effect on $\mathrm{N}_{2} \mathrm{O}$ flux if the slurry was treated one hour before application; if treated one week before application, fluxes were much higher from $\mathrm{pH}-6.0$ slurry than from $\mathrm{pH}-4.5$ slurry.

\section{Acknowledgements}

The authors thank Richard Oomkens for his technical assistance. This investigation was supported financially by 'Financierings Overleg Mest- en Ammoniakonderzoek' (FOMA).

\section{References}

Beauchamp, E.G., J.T. Trevors \& J.W. Paul, 1989. Carbon sources for bacterial denitrification. In: B.A. Stewart (Ed.), Advances in Soil Science 10, p. 113-142. Springer-Verlag, New York.

Blackmer, A.M., S.G. Robbins \& J.M Bremner, 1982. Diurnal variability in rate of emission of nitrous oxide from soils. Soil Science Society of America Journal 46: 937-942.

Bouwman, A.F. (Ed.), 1990. Soils and the greenhouse effect. John Wiley \& Sons, Chichester, 575 pp.

Bussink, D.W. \& M.A. Bruins, 1992, Reduction in ammonia volatilization using different slurry application techniques on grassland. (In Dutch). Meststoffen: 31-36.

Denmead, O.T, J.R. Freney \& J.R. Simpson, 1979. Studies of nitrous oxide emission from a grass sward, Soil Science Society of America Journal 43: 726-728.

Eichner, M.J., 1990. Nitrous oxide emissions from fertilized soils: summary of available data. Journal of Environmental Quality 19: 272-280. 


\section{NITROUS OXIDE FLUX FROM NITRIC-ACID-TREATED CATTLE SLURRY}

,

Pirestone, M.K. \& E.A. Davidson, 1989. Microbiological basis of $\mathrm{NO}$ and $\mathrm{N}_{2} \mathrm{O}$ production and consumption in soil. In: M.O. Andreac \& D.S. Schimel (Eds), Exchange of Trace Gases between Terrestrial Ecosystems and the Atmosphere, Life Sciences Research Report 47, p. 7-21. John Wiley \& Sons, Chichester.

Frost, J.P., R.J. Stevens \& R.J. Laughlin, 1990. Effect of separation and acidification of cattle slurry on ammonia volatilization and on the efficiency of slurry nitrogen for herbage production. Journal of Agricultural Science (Cambridge) t15: 49-56.

Keeney D.R., I,R. Fillery \& G.P. Marx, 1979. Effect of temperature on the gaseous nitrogen products of denilrification in a silt loam soil. Soil Science Society of America Journal 43: 1124-1128.

Mosier, A.R, 1989. Chamber and isotope techniques. In: M.O. Andreae \& D.S. Schimel (Eds), Exchange of Trace Gases between Terrestrial Ecosystems and the Atmosphere, Life Sciences Research Report 47, p. 175-187, John Wiley \& Sons, Chichester.

Oenema, O. \& G.L. Velithof, 1993. Denitrification in nitric acid treated cattle slurry during storage. Netherlands Journal of Agricultural Science 41: 63-80.

Oenema, O., G.L, Velthof \& D.W. Bussink (1993). Emissions of ammonia, nitrous oxide and methane from cattle slurry. In: R.S. Oremland (Ed.). The Biogeochemistry of Global Change: Radiative Trace Gases, p, 419-433. Chapman and Hall, New York.

Pain, B.F., R.B. Thompson, Y.J. Rees \& J.H. Skinner, 1990. Reducing gaseous losses of nitrogen from caltle slurry applied to grassland by the use of additives. Journal of the Science of Food and Agriculinure 50: 141-153.

Ryden, J.C. \& D.E. Rolston, 1983. The measurement of denitrification. In: J.R. Freney and J.R. Simpson (Eds), Gaseous loss of nitrogen from plant-soil systems. Developments in Plant and Soil Sciences, Vol. 3, p. 91-132. Martinus Nijhoff, Dordrecht.

Stevens, R.J., R.J. Laughlin \& J.P. Frost, 1989. Effect of acidification with sulphuric acid on the volatilization of ammonia from cow and pig slurries. Journal of Agricultural Science (Cambridge) 113: 389-395,

Stevens, R.J., R.J. Laughlin, J.P. Frost \& R. Anderson (1992). Evaluation of separation plus acidification with nitric acid and separation plus dilution to make cattle slurry a balanced, efficient fertilizer for grass and silage. Journal of Agricultural Science (Cambridge): 119: 391-399. 